\title{
An innovative STEM outreach model (OH-Kids) to foster the next generation of geoscientists, engineers, and technologists
}

\author{
Adrián Pedrozo-Acuña ${ }^{1,2}$, Roberto J. Favero Jr. ${ }^{1,2}$, Alejandra Amaro-Loza ${ }^{1}$, Roberta K. Mocva-Kurek ${ }^{1}$, \\ Juan A. Sánchez-Peralta ${ }^{1,2}$, Jorge A. Magos-Hernández ${ }^{1,2}$, and Jorge Blanco-Figueroa ${ }^{1}$ \\ ${ }^{1}$ Universidad Nacional Autónoma de México, Instituto de Ingeniería, Av. Universidad 3000, \\ Coyoacán, 04510, Mexico City, Mexico \\ ${ }^{2}$ Mexican Institute of Water Technology (IMTA), Paseo Cuauhnáhuac 8532, Col. Progreso Jiutepec, Morelos, Mexico
}

Correspondence: Adrián Pedrozo-Acuña (apedrozoa@ii.unam.mx)

Received: 30 April 2019 - Discussion started: 3 July 2019

Accepted: 24 October 2019 - Published: 4 December 2019

Abstract. Childhood education programmes aiming at incorporating topics related to science, technology, engineering, and mathematics (STEM) have gained recognition as key levers in the progress of education for all students. Inspiring young people to take part in the discovery and delivery of science is of paramount importance not only for their well-being but also for their future human development. To address this need, an outreach model entitled OH-Kids was designed to empower pupils through the development of high-quality STEM learning experiences based on a research project. The model is an opportunity for primary school learners to meet geoscientists while receiving the take-home message that anyone can get involved in scientific activities. The effort is part of a research project aimed at the real-time monitoring of precipitation in Mexico City, which is a smart solution to rainfall monitoring using information and communications technologies. The argument behind this effort is that in order to produce the next generation of problemsolvers, education should ensure that learners develop an appreciation and working familiarity with a real-world project. Results show success at introducing the role of researchers and STEM topics to 6-12-year-old learners.

\section{Introduction}

Inspiring young people to take part in the discovery and delivery of science, technology, engineering, and mathematics (STEM) has been proven to contribute significantly not only to their well-being, but also to their future human de- velopment (Bertram and Pascal, 2016; Morgan et al., 2016; Friedman-Krauss et al., 2018). However, the current system uses teaching and learning methods that tend to develop geoscientists, engineers, and technologists only by mere chance. It seems that, in far too many cases, teachers and/or syllabi unintentionally deter potential STEM learners - especially girls - due to the way they choose to teach science, mathematics, design, and technology.

Moreover, in several countries, such as the United Kingdom, STEM topics do not appear on the timetables of pupils of primary or lower secondary age (Bianchi and Chippindall, 2018). This is also the case in Mexico, where promoting and improving student engagement on these topics constitutes a great challenge for teachers. This is ascribed to the lack of professional guidance for early childhood educators, who rarely receive in-depth professional training for teaching STEM (Brenneman et al., 2009).

Primary and secondary education have been found to be significant periods for developing students' interest in science and technology (Maltese et al., 2014). At these stages, pupils' interest in science is closely related to the level of appreciation of its applicability in their lives. Therefore, it is important to incorporate activities in the classroom that convey the wider relevance of science to everyday life (Sheldrake et al., 2017). This may encourage students' aspirations towards science and engineering careers (Regan and DeWitt, 2015).

On the other hand, scientific and technological education is evolving rapidly with the advancement of the digital age, so it is inevitable for pupils and academics to transition to the 
development and use of new strategies that allow the overcoming of observed difficulties in the teaching-learning process (Souza et al., 2018). The generation of new strategies of STEM communication to children constitutes a critical step towards improving not only their learning experience, but also their teaching practice.

It has been acknowledged that promoting the relevance and utility of science to students enhances their interest in science and boosts their attainment (Rozek et al., 2015; DeWitt and Archer, 2015; Savelsbergh et al., 2016; Sheldrake, 2016). In this regard, a good strategy for promoting meaningful learning is the development and implementation of educational activities through the exposure of pupils to a realworld application of STEM (Smith et al., 2005). The argument behind this effort is that, in order to produce the next generation of problem-solvers, education should ensure that learners develop an appreciation of and a working familiarity with STEM disciplines and human-environmental systems (Brenneman et al., 2018).

Within this context, the research question that motivates this study is as follows: "is it possible to enhance learning experiences of STEM disciplines for students (age 6-12), using a water resource research project and different pedagogical strategies?" Therefore, this study demonstrates an innovative teaching strategy via the outreach model entitled $\mathrm{OH}$ Kids, created to empower pupils through the development of STEM learning experiences focused on water resources and based on a research project. Furthermore, the study presents the results of its application in schools of Mexico City.

The initiative is part of the real-time Hydrological Observatory of the National Autonomous University of Mexico's Institute of Engineering (OH-IIUNAM), which includes a research project aimed at the real-time monitoring of precipitation in Mexico City (Pedrozo-Acuña et al., 2017). The system represents a smart-water solution comprised by the application of information and communications technologies within an urban environment. Notably, the framework highlights the integration of geoscientists from hydrology, meteorology, and geology, as well as technologists and various practical engineering specialists (hydraulics, electronics).

The outreach model OH-Kids was born from the interaction of the team behind this research project with primary school educators. This communication resulted from the installation of 54 stand-alone stations to measure precipitation in Mexico City, 15 of which were installed on the rooftops of primary schools and 9 on the rooftops of secondary schools. In the primary schools, the equipment installation process prompted the interest of educators and pupils in the apparatus and the wider application of science and engineering in the project. This research project was therefore seen as an opportunity to develop an innovative approach focused on improving the attitudes of the students towards science and engineering.

Applied in several primary schools and one science fair in Mexico City, the programme has a design strategy based on principles relevant to all researchers working with educators in settings that include families from different social backgrounds. The paper is organized as follows: Sect. 2 presents a methodological description of the outreach model, Sect. 3 introduces the results of the implementation of this programme, and finally Sect. 4 summarizes the main conclusions.

\section{OH-Kids: a STEM outreach model}

The OH-Kids outreach model comprises a collaborative and effective researcher-educator-learner communication strategy - built around constructivist pedagogy, sociocultural theory and principles of engagement, guided discovery, experiential, and game-based learning - to encourage STEM subject uptake. In this sense, the model was designed following an approach that involves the exposure of learners to a realworld-application STEM project using games and hands-on activities as educational and didactic tools (Parson and Miles, 1994; Poljak et al., 2018). Our proposal for the model design was based on different documented efforts that had an effect on classroom practice and child outcomes (Design-Based Research Collective, 2003; Drago-Severson, 2009; Zaslow et al., 2010).

Following Rogers et al. (1988), the activities are designed on the basis that involvement of children is beneficial for their learning process, using their innate curiosity as a starting point (McIntyre, 1984; Piaget, 1971). Educational games and activities have been recognized as a valid strategy to enhance student engagement and develop key skills that may be applicable in other contexts, such as the ability to work as a team (Butucha, 2016; Garris et al., 2002). Students learn as a consequence of playing, which promotes meaningful learning (Croxton and Kortemeyer, 2018).

The creation of a learning experience that promotes participation and science teaching in an active learning environment has positive effects on all children regardless of their literacy and social origin. Indeed, this approach has been found to create a rich learning environment that is accessible to all the students in the classroom (Fantuzzo et al., 2011; Sarama et al., 2012). Furthermore, studies have shown that there is a correlation between positive experiences in science as a child and a strong interest in and a positive perception of science as an adult (Falk et al., 2017).

The intention of the OH-Kids outreach model is to enhance thinking skills related to STEM disciplines with a focus on water resources in the classroom, in addition to highlighting the use of science and engineering for everyday life and the wellbeing of society. The OH-Kids model can serve as an example to other researchers and teachers interested in childhood STEM education. It can also support different learners in other settings, such as museums and science centres.

The model's main objectives are as follows: 
a. to enable pupils to meet a scientific team and find out what scientists do and how research is carried out,

b. to improve understanding of hydrology, specifically the water cycle, and the relationship between water and cities,

c. to enhance children's experience of science and technology,

d. to demonstrate links between topics covered in school curricula and research projects in the real world,

e. to know the extent to which this methodology results in changes in learners' enjoyment and perception of science and scientists.

The model is akin to a workshop and includes two types of activities (Table 1). The first one is related to traditional academic strategies: a short lecture that explains the real-world problem and associated concepts. The second one consists of interactive and ludic activities that are implemented within the classroom as didactic tools for teaching the STEM disciplines involved in water resources. All activities are organized in a circuit that enables the alternation of an academic activity with one of a more ludic nature, which can be considered as one of the innovations of this outreach model. Figure 1 illustrates a flow chart of the order of activities during the $\mathrm{OH}$-Kids workshop.

In order to assess modifications in pupils' perceptions of some basic concepts related to water resources, as well as their perceptions of science and scientists, resulting from the application of our model, we designed a diagnosis and final questionnaire. Similar instruments have been documented to establish attitudes within educational research (Muller et al., 2013; OECD, 2016). Tables 2 and 3 show the questions incorporated in these questionnaires. The first five questions were designed to examine how their perception of water concepts changed after their participation, while the last four served to evaluate how much their attitude towards science had changed.

The diagnostic questionnaire is applied before the workshop, which allows a baseline of students' perceptions in relation to science and their level of understanding of basic water science concepts to be established. After all activities, the final questionnaire was applied to obtain feedback from the students about the subjects seen. This evaluation instrument helps to infer the students' perceptions towards water science, scientists, and technology before and after its application.

In summary, the $\mathrm{OH}$-Kids workshop incorporates a series of activities implemented in a successive order (shown in Table 3) along with the time duration and number of students per activity. The total time for this workshop is $120 \mathrm{~min}$ per classroom or group of 30 students, depending on the application of the evaluation instrument. The activities are applied by the multidisciplinary scientific project team that comprise civil, electronic and environmental engineers; biologists; physicists; and educators. However, teachers are also encouraged to work with the team to encourage active pupil participation.

The activities workshop starts with a short talk introducing real-time rainfall monitoring system at urban scales and concepts related to water science and technology (i.e. water footprint, hydrological cycle, precipitation, cloud and precipitation formation, etc.), highlighting the integration of mathematics and technology concepts (i.e. instrumentation and measurement of precipitation, etc.). This mini-talk is aimed at highlighting the importance of water for the planet, the cities, and their own lives. One important topic that is addressed are units of measurement and unit conversion with the objective that pupils comprehend the significance between "1" $\mathrm{mm}$ of rainfall and larger quantities and its implication in an urban area.

In the sequence, the group of students is divided into five sub-groups of six students for the application of the activities circuit. This subdivision is carried out to enable the participation of all learners within each activity and to improve teacher-learner relationships, which contributes to a better learning process. In addition, it is acknowledged that low-, medium-, and high-ability students all benefit when being taught in small heterogeneous groups. The learning process of low-ability students may especially suffer risks in homogeneous, teacher-led groups (Wilkinson and Fung, 2002).

The whole circuit comprises a range of interactive and ludic activities of short duration (15 min), which are shown as shaded cells in Table 3. These activities are performed simultaneously by each student sub-group, which alternates between different activities every 15 min (as shown in Fig. 1). These activities incorporate the work of a facilitator per activity, who supports students who are not willing or able to participate without help. Once all the smaller groups have completed the five activities, the students are regrouped into one plenary session to conclude the workshop and apply the final evaluation questionnaire.

Considering that each person learns in a different way, the idea of using a circuit of ludic and interactive activities in the workshop is to provide students with different sensory-motor stimuli to increase intellectual engagement (i.e. Windschitl et al., 2018). Informal learning settings, such as the one developed here, have been identified as opportunities to enhance students' knowledge and to optimize the connection between science and everyday life (Martin et al., 2016).

The five activities of the circuit were developed considering visual and tactile stimuli, as well as observation, attention, memory, and concentration. In addition, they were put together to reinforce the concepts introduced in the initial talk and to spark interest in STEM disciplines, using evidence and demonstrations from the research project as a basis (Renninger and $\mathrm{Su}, 2012$ ). It is important to mention that some activities were adapted (water bingo, memory games, 


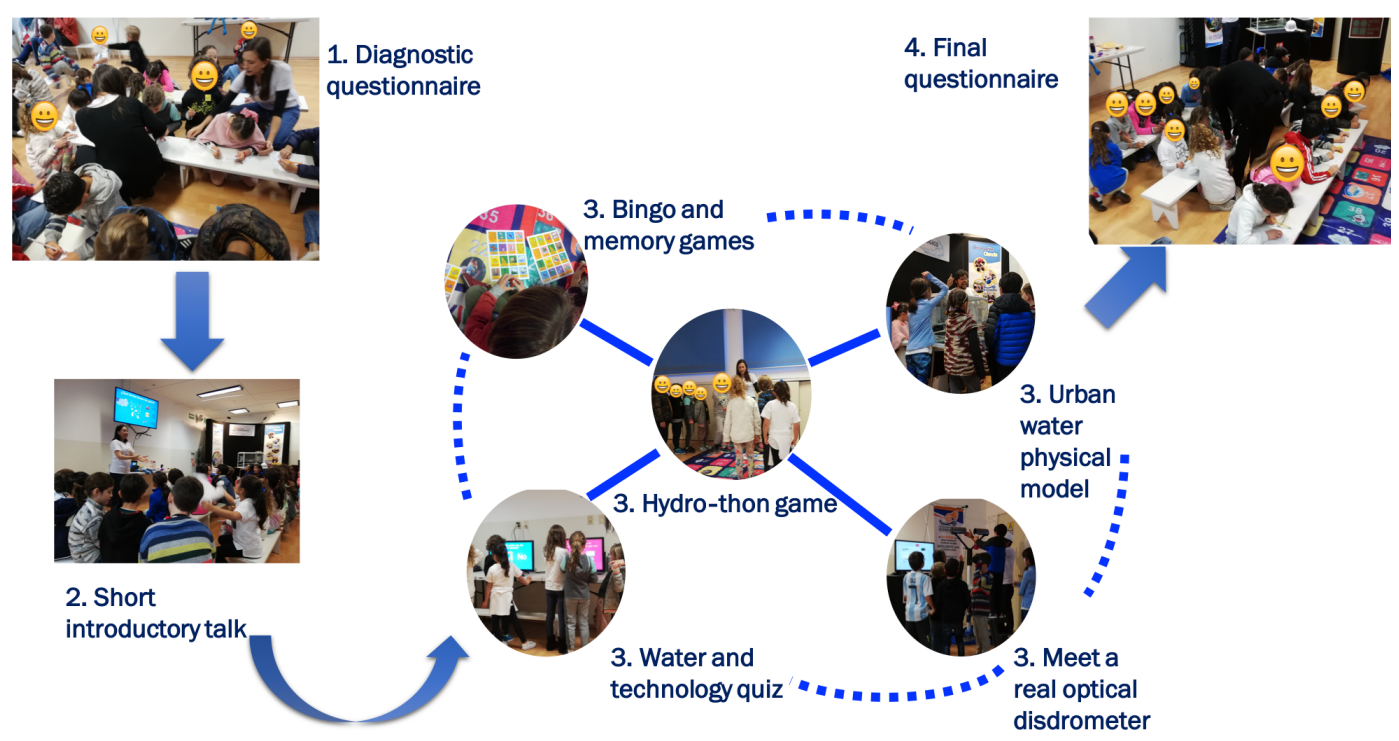

Figure 1. Schematic view of the order of activities performed during the OH-Kids workshop.

Table 1. Sequence of OH-Kids workshop activities along with time duration and number of students (italic lines comprise the simultaneous activities of the circuit).

\begin{tabular}{llrrr}
\hline Order & Activity & $\begin{array}{r}\text { Duration } \\
\text { (minutes) }\end{array}$ & $\begin{array}{r}\text { Number of } \\
\text { learners }\end{array}$ & $\begin{array}{r}\text { Number of } \\
\text { groups }\end{array}$ \\
\hline 1 & Diagnostic questionnaire & 15 & 30 & 1 \\
2 & Short introductory talk & 15 & 30 & 1 \\
3 & Water bingo/memory & 15 & 6 & 5 \\
3 & Urban water physical model & 15 & 6 & 5 \\
3 & "Hydro-thon", a water and technology board game & 15 & 6 & 5 \\
3 & Meet and play with a real optical disdrometer & 15 & 6 & 5 \\
3 & Water and technology quiz & 15 & 6 & 5 \\
4 & Evaluation questionnaire & 15 & 30 & 1 \\
\hline Summary per classroom total & 120 & 30 & 1 \\
\hline
\end{tabular}

Hydro-thon) and others elaborated (meet a real optical disdrometer, urban water physical model) by the team.

Perhaps the most important characteristic of the workshop is that it enables new ways of imparting knowledge related to a real research project to children, fostering the use of wonder as a pedagogical tool for emotional and aesthetic engagement with science (Gilbert and Byers, 2017). What follows is a brief description of each activity.

\subsection{Water bingo and memory games}

The development and widespread use of games began a revolution in thinking about their potential role for nonentertainment domains. Moreover, it has been acknowledged that many students may not respond strongly to instruction that they do not perceive as engaging. This is why the use of games has been regarded as a useful pedagogical approach to help engage students (Bodnar et al., 2016). Educational games may provide students with a motivating and stimulating environment while providing them with immediate feedback to promote learning (Zyda, 2005). In particular, card and board games improve communicative skills and promote active learning through interaction with other players (Neame and Powis, 1981; Richardson and Brige, 1985). The use of memory gaming is recognized as an activity that stimulates basic cognitive functions, such as attention, concentration, and memory (Connolly et al., 2012).

Considering this, the workshop incorporates one activity related to the use of classical memory games and bingo adapted to reinforce words and concepts related to research projects and STEM. Water bingo is a variation of the bingo game, which uses images on boards and cards instead of plain numbers on ping-pong balls. Figure $2 \mathrm{a}$ shows the boards and cards used for the game. Every image represents a term in relation to one of following topics: (1) concepts of hydrology (i.e. water cycle, hyetograph, type of pre- 
Table 2. Diagnostic evaluation questionnaire of learners' perceptions to science, scientists, and basic concepts related to water resources.

\begin{tabular}{|c|c|c|c|c|}
\hline Name: & & & Grade: & \\
\hline \multicolumn{5}{|c|}{ Mark with an " $X$ " the box that better represents your reply. } \\
\hline & Not at all & A little & Somewhat & A lot \\
\hline \multicolumn{5}{|l|}{1 Can you explain the water cycle? } \\
\hline \multicolumn{5}{|l|}{2 Do you know the meaning of water footprint? } \\
\hline \multicolumn{5}{|l|}{3 How important is it to measure precipitation? } \\
\hline \multicolumn{5}{|l|}{$\begin{array}{l}4 \text { How much do you know about the instrument to } \\
\text { measure rainfall located in your school? }\end{array}$} \\
\hline \multicolumn{5}{|l|}{$\begin{array}{l}5 \text { Do you know where to consult rainfall data for } \\
\text { Mexico City? }\end{array}$} \\
\hline \multicolumn{5}{|l|}{6 Do you think that science is interesting? } \\
\hline \multicolumn{5}{|l|}{7 Would you like to become a scientist? } \\
\hline \multicolumn{5}{|l|}{$\begin{array}{l}8 \text { Do you agree with this sentence? } \\
\text { Science is difficult. }\end{array}$} \\
\hline 9 Do you like to carry out experiments? & & & & \\
\hline
\end{tabular}

Table 3. Final evaluation questionnaire to assess changes in learners' perceptions to science, scientists, and basic water resources concepts.

\begin{tabular}{|c|c|c|}
\hline Name: & & Grade: \\
\hline \multicolumn{3}{|c|}{ Mark with an " $X$ " the box that better represents your reply. } \\
\hline & Not at all $\mid$ A little & Somewhat $\mid$ A lot \\
\hline 1 Do you understand the water cycle better now? & & $\mid$ \\
\hline 2 Can you help reduce the water footprint? & & $\mid$ \\
\hline 3 How important is to measure precipitation? & & $\mid$ \\
\hline 4 Can you explain how a disdrometer works? & & $\mid$ \\
\hline 5 Do you know where to consult rainfall data? & & | \\
\hline 6 Do you think that science is interesting? & & $\mid$ \\
\hline 7 Would you like to become a scientist? & & 1 \\
\hline $\begin{array}{l}8 \text { Do you agree with this sentence? } \\
\text { Science is difficult. }\end{array}$ & & \\
\hline 9 Do you like to carry out experiments? & & 1 \\
\hline
\end{tabular}

cipitation), (2) meteorology concepts (i.e. hurricane, floods, climate change), (3) technological terms (i.e. solar panel, weather radar, Raspberry $\mathrm{Pi}$ ), and (4) names of $\mathrm{OH}$ stations.

The board contains 16 random images and the deck of cards is composed of a set of 31 different images (concepts), one for each card. Figure 3 shows an image of a group of students playing water bingo. To start the game, each player gets one board and the instructor randomly selects a card from the deck, calling out the definition instead of reading the card name. For example, the instructor says, "it's a small and af- fordable computer", and the players mark with a red token the Raspberry Pi image on their boards. The first player to complete the board and shout "bingo" wins the game.

The water memory game contains 10 pairs of cards with different images related to the same concepts and terms of the bingo game. Figure $2 \mathrm{~b}$ shows an image of these cards. Throughout the game, players are encouraged to try to remember the concept associated with each card image. 

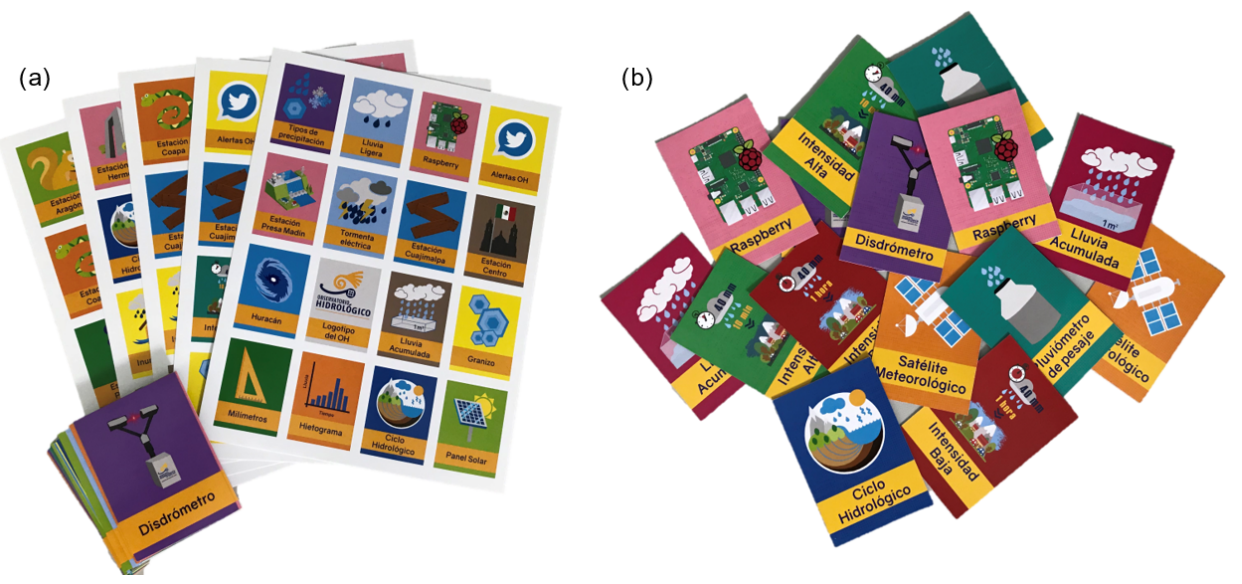

Figure 2. Water bingo boards and cards (a) and memory cards (b) designed for the workshop.

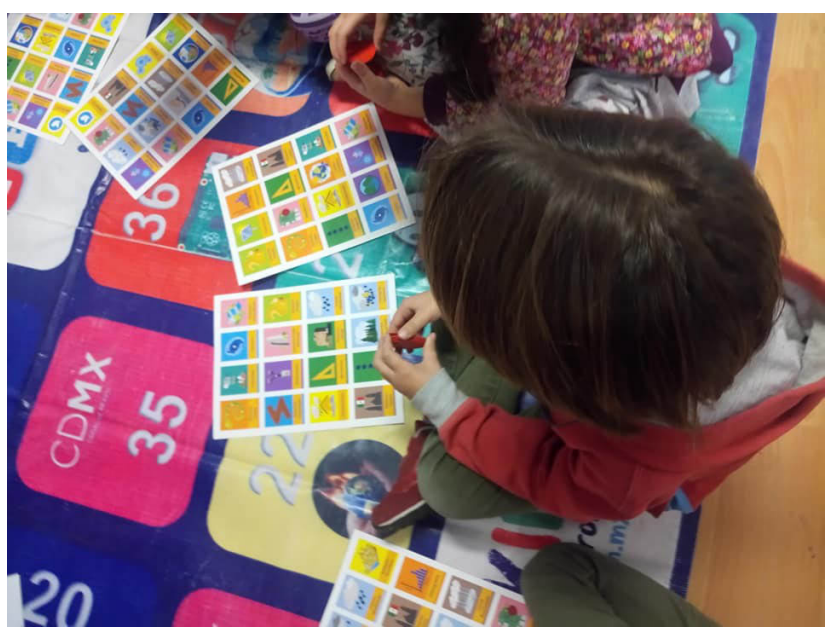

Figure 3. Group of students playing water bingo during one of the workshops.

\subsection{Urban water physical model}

Physical models located in laboratories have been an essential part of undergraduate and, in some cases, graduate programmes in engineering (Feisel and Rosa, 2005). They have been recognized as serving an educational purpose and providing physical intuition (van Os et al., 2010) and are also assumed to reflect the empirical nature of science (Millar, 1998). Given the importance of this pedagogic tool, we considered the use and construction of a simple urban water physical model in our workshop to illustrate how heavy rainfall saturates urban drainage systems, producing floods. Our physical model consists of a small-scale city within a glass case, a miniature urban drainage, and a rainfall simulator (Fig. 4a, b, and c, respectively).

The drainage system is made up of four orifices that represent the sewers, which are connected with PVC drainage pipes. For the rainfall simulator, PVC pipes and two water pumps (low- and high-flow rate) are used. This system allows us to simulate three rainfall intensities through flow combinations: light, moderate, and heavy rainfall. With the physical model, we can simulate the development of urban floods, i.e. when a city's sewage system and drainage pipes do not have the necessary capacity to drain away the amount of rain that is falling. Figure 5 illustrates a small group of students actively participating in the activity.

The OH-Kids team encourages the pupils to discuss floods, for instance, how widespread they are, how they affect cities and people, and how their effects can be mitigated. They foster debate and argumentation to reflect aspects of scientific inquiry, such as reasoning and justification (Sheldrake et al., 2017). The pupils were impressed to find out what a drainage system is, how it works, and how important it is; they also argued a lot about the importance of throwing the garbage in the right place and the danger of walking on the street when rain is very strong. The response of students to this activity clearly shows an enhanced interest in and perceived utility of science, as observed in recent educational research (Savelsbergh et al., 2016).

\subsection{The Hydro-thon game}

This game was created by the $\mathrm{OH}-\mathrm{Kids}$ team inspired on the Mexican board game "Maratón", created by Sergio Schaar in the 1970s with the aim reinforcing the school knowledge of players. This game is a carefully designed activity to introduce topics related to climate, hydrology, engineering, and technology to 6-12-year-old learners. In this sense, it may be used as a didactic tool for teaching STEM involvement in water-related issues.

This game is easy to play, because the rules are simple and can be quickly learned. Furthermore, it requires few physical resources: a board, question cards, and a dice. Therefore, this game is useful in any educational environment regardless of social realities. 


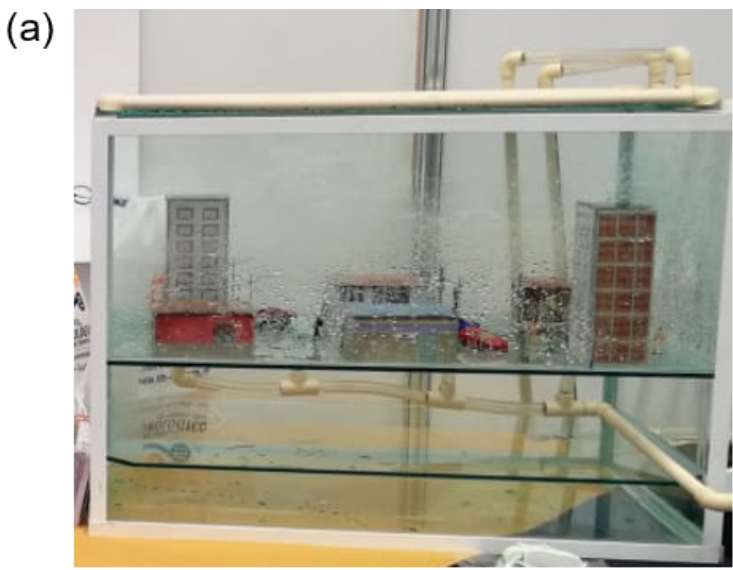

(b)

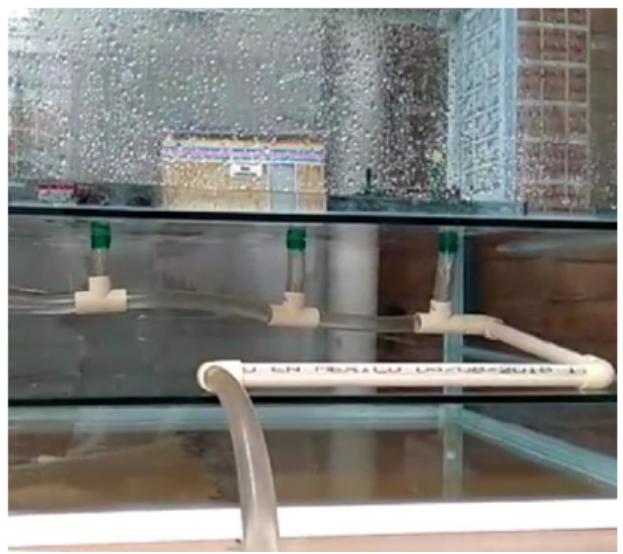

(c)

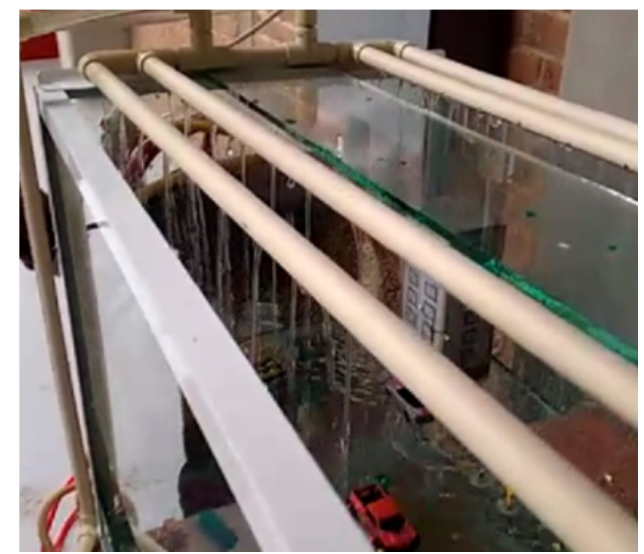

Figure 4. Details of the urban water physical model constructed for the OH-Kids workshop: (a) glass case with representation of small-scaled city, (b) urban drainage system, and (c) rainfall simulator.

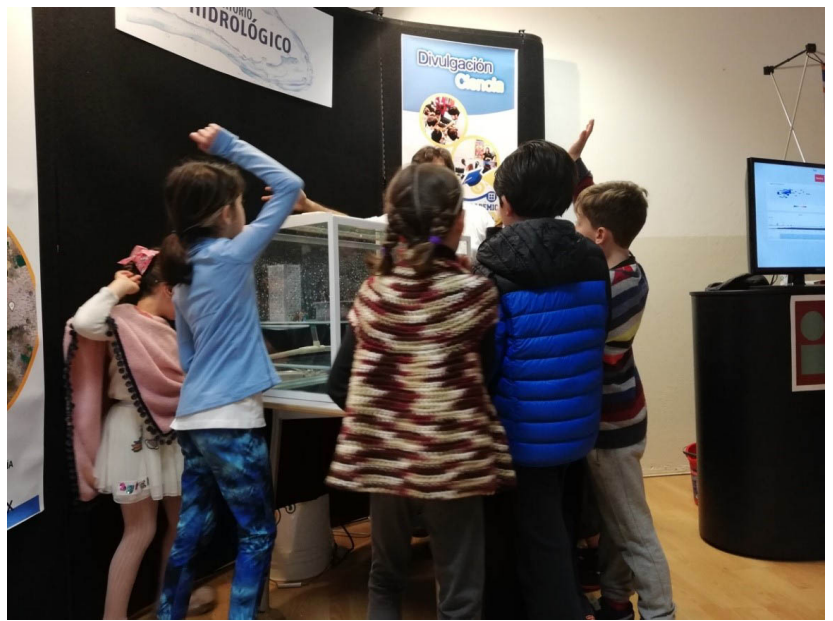

Figure 5. Group of students participating in the "urban water physical model" activity.
Hydro-thon can be played by a minimum of two players and by up to eight players grouped in pairs. Figure 6 illustrates the game board (a game mat, rather), which comprises 40 cells of six different colours that represent each category of questions. These categories consist of the following topics: (1) climate science (blue), (2) technology (red), (3) water education (green), (4) urban water (pink), (5) the water cycle (orange), and (6) climate change (yellow). The questions are organized according to level of knowledge (basic, intermediate, and advanced).

The player (or pair of players) moves on the game mat, starting at the home cell (OH-Kids cell), by as many cells as indicated by the dice throw. The resulting cell (identified by colour) determines what category of question that player needs to answer. Within a category, the question is selected according to the difficulty level of the participants. This allows the youngest pupils to answer basic questions. If the player answers the question correctly, he or she moves one cell forward. In contrast, if the answer is not correct, the player stays at the same cell. Figure 7 shows a group of children playing Hydro-thon during a workshop. In summary, 


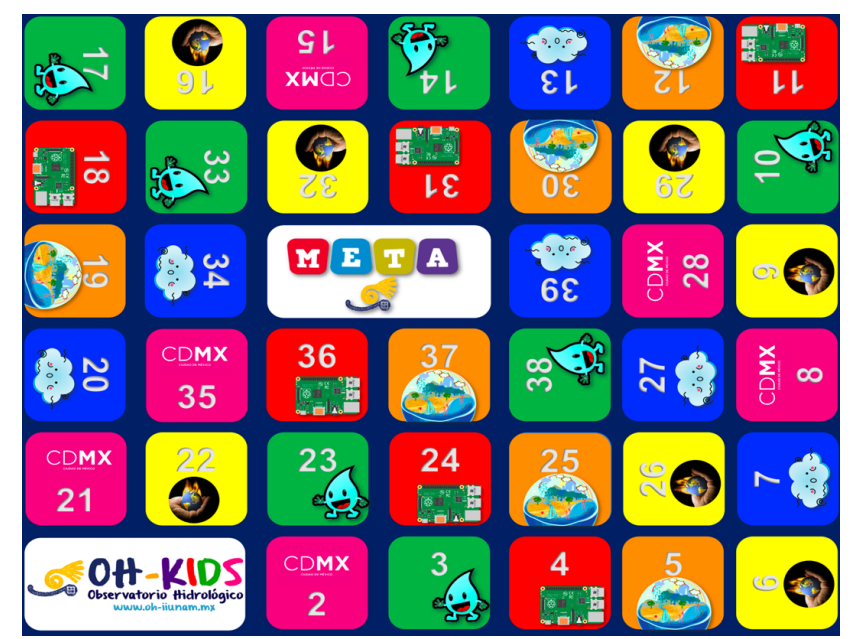

Figure 6. The Hydro-thon game mat.

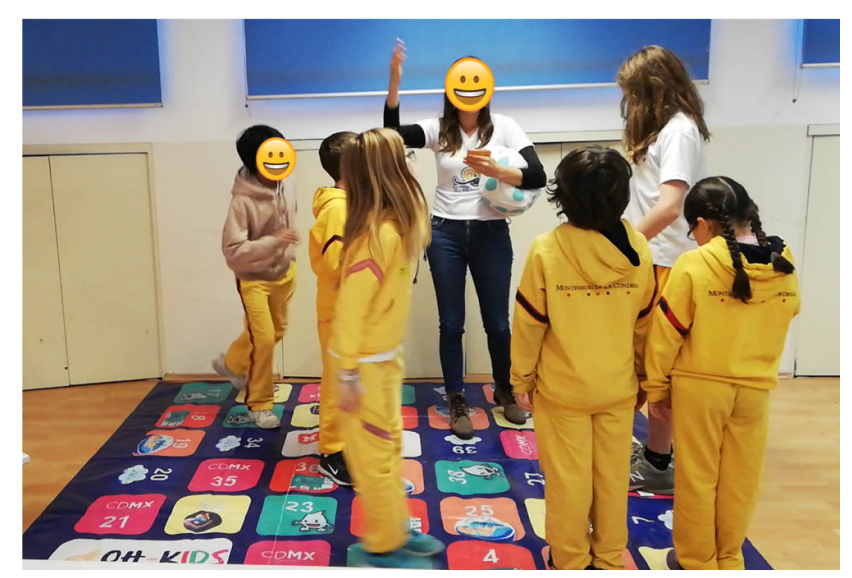

Figure 7. A small group of students playing Hydro-thon during one of the workshops.

the game reviews how well concepts were understood by the students in a relaxed atmosphere.

\subsection{Meet and play with a real optical disdrometer}

This is another key activity within the workshop, which allows students to experience a real rainfall measurement instrument from the OH-IIUNAM research project. This activity enables students to witness how precipitation is measured by the optical instrument through a fun challenge.

Students "generate rainfall" by activating a water spray bottle within the measurement area of the instrument. The data acquisition system designed especially for this activity acquires rainfall variables, such as intensity, raindrop diameters, and fall velocity. The numerical information is immediately displayed through graphs in a screen minute by minute. The data acquisition system used in the demonstration is similar to the one used in the real research project.

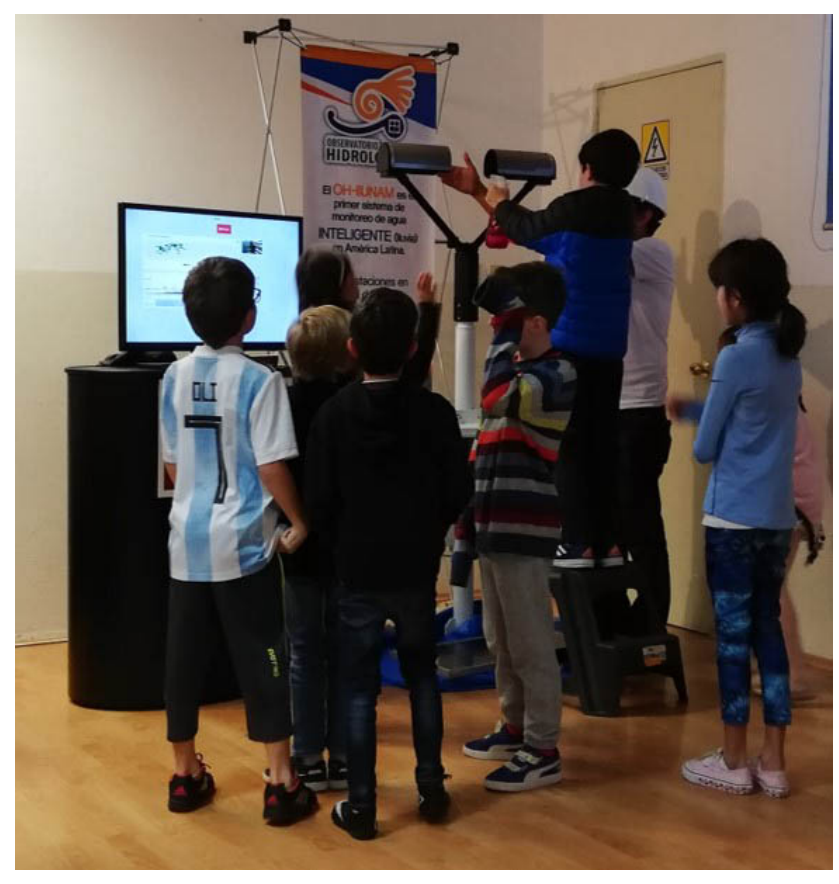

Figure 8. A group of students participating in the "meet and play with a real optical disdrometer" activity.

Students feel enthusiastic about the challenge, trying to do their best in order to obtain a maximum amount of rainfall or calculate the raindrops simulated with a water spray bottle. The $\mathrm{OH}$ team encourage pupils to interpret the information measured and displayed as graphs, thereby obtaining the ability to distinguish the difference between small and large rainfall quantities and the fact that the rain drops do not have the same size. After the challenge, the OH-Kids team explains the functioning of the disdrometer in order to complement their learning.

Occasionally, students repeated the same mistake of spraying perpendicularly to the laser beam instead of orthogonally, because rain falls perpendicularly to the ground. All information is transmitted in a playful and fun way, so that students can understand and feel motivated to participate. Figure 8 shows a group of students carrying out this activity, with the screen monitor displaying the real-time rainfall variables measured.

This activity has a double benefit: on the one hand, it allows the contextualization of concepts provided during the introductory talk and, on the other, it sparks students' curiosity for technology. It also teaches how a scientific question (e.g. how is rainfall measured? Are all the drops the same size?) can be answered through the interaction of different technological disciplines, such as electronic, computing, and hydrologic engineering. It demonstrates as well the different levels of complexity of practical applications and real-life environmental problems, which are often overlooked by traditional lectures. 
In summary, this hands-on activity - based on an exploratory learning environment that allows students to challenge their knowledge and awaken their curiosity - creates a propitious setting for self-discovery and develops selfcriticism about the unknown. This environment provides an internal reward to the student, allowing them to achieve personal fulfilment, and can change initial perceptions of the topics in question. Therefore, this activity can be considered as an excellent tool for teaching how rainfall is measured.

\subsection{Water and technology quiz}

Among the technological activities designed for the reinforcement of key water science and hydrological concepts is the implementation of a quiz game. It has been recognized that students can learn academic content and have fun while playing educationally relevant games. Moreover, games can promote teamwork and cooperation (Steinberg, 2011) and help build their academic confidence (Education World, 2015).

In agreement with Bochennek et al. (2007) games could be seen as experiential learning cycles in that they repeat learning stages in each game turn or every game played. In this context, the authors mention that games can be classified in various model stages according to the different learning processes involved. The quiz developed for our workshop may be categorized as a two-stage model (Bochennek et al., 2007, based on Bacon, 1987), where experience is followed by reflection.

This game is displayed in an interactive monitor through a presentation editor software and consists of 10 questions about water and technology. Players need to answer the quiz sequentially and a point is given for each correct answer. The quiz can be played individually or in pairs (as we played it). Considering the learning process, this game replicates an exam-like situation, but in an interactive setting. Figure 9 shows a group of students playing the quiz game during one of our workshops.

Among the main benefits associated with the implementation of games for educational purposes is the immediate feedback and letting the students know that they are making progress (Bodnar et al., 2016), as attested by the water and technology quiz. In addition, the engagement of students has been recognized as especially important in science and engineering education, and applying a technological activity makes this possible, while traditional lectures often fail in this regard (Drew, 2011).

\section{Results and discussion}

The methodology of the OH-Kids model was evaluated by comparing diagnostic and final questionnaires applied during the workshop. This enables us to verify if this workshop produces changes in learners' enjoyment and perception of science, scientists, and basic water-resources concepts. This

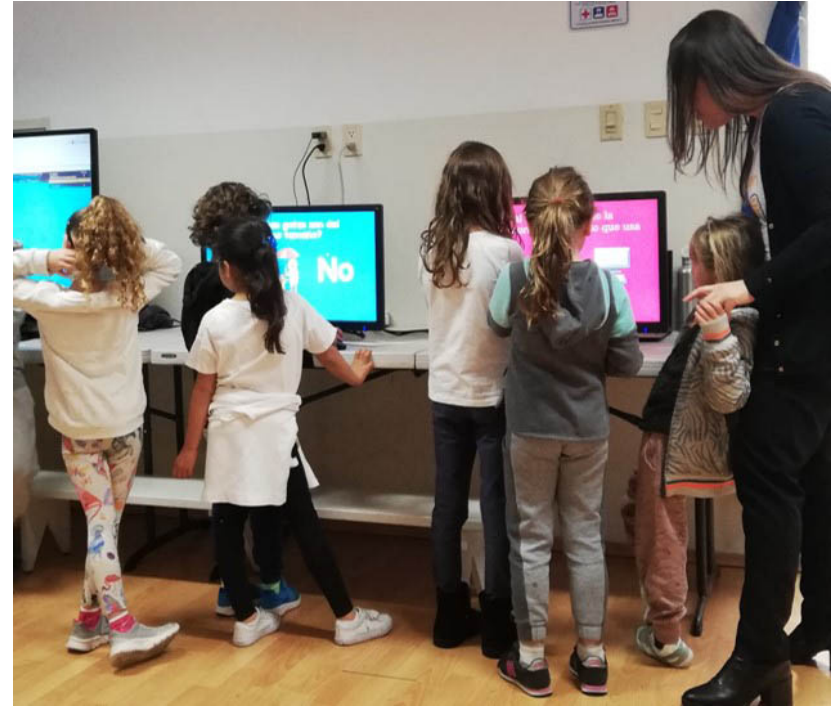

Figure 9. A group of students playing the water and technology quiz during one of the workshops.

workshop was applied in six different schools located in Mexico City that represent a sample of $N=344$ primary school students (aged 6-12 years), so the results integrate answers from the whole sample.

Figure 10 presents the compiled statistics of before-andafter answers to the questions related to water concepts by the whole sample of 344 students (questions 1-5 in Tables 2 and 3). This figure demonstrates the efficiency of the workshop on key water concepts that were not clear to the students at the beginning of the workshop. For instance, before the workshop, results show that only $30 \%$ of all the students answered "a lot" to the question of how much they know about the water cycle. The reply to this question after the workshop rose to $75.6 \%$ of students being able to answer "a lot". The same occurred with the question related to the water footprint, which is a more elaborate concept than that of the water cycle. In this case, $65.7 \%$ of the students admitted not knowing anything at all on this matter; however, after the workshop, this value reduced to only $5.8 \%$ of the students. In the case of measuring rainfall, before the workshop only $53.5 \%$ recognized its importance, while this number rose to $88.95 \%$ after the workshop.

One of the objectives of the workshop was to change the student's perception of what a scientist is and does; therefore we designed a series of questions in order to assess whether this workshop could contribute to increasing the numbers of students who would be keen on becoming a scientist. In this sense, Fig. 11 shows the compiled percentages of answers related to this topic (questions 6-9 in Tables 1 and 2), considering the whole sample, where it is evident that there is less variation in the students' responses. Results indicate that prior to the workshop, $76.45 \%$ of all students thought science was interesting, with this number increasing to $82.45 \%$ 
(a) Diagnostic evaluation

How much do you know about ...? (b) Final evaluation

How much more did you learn about ... ?

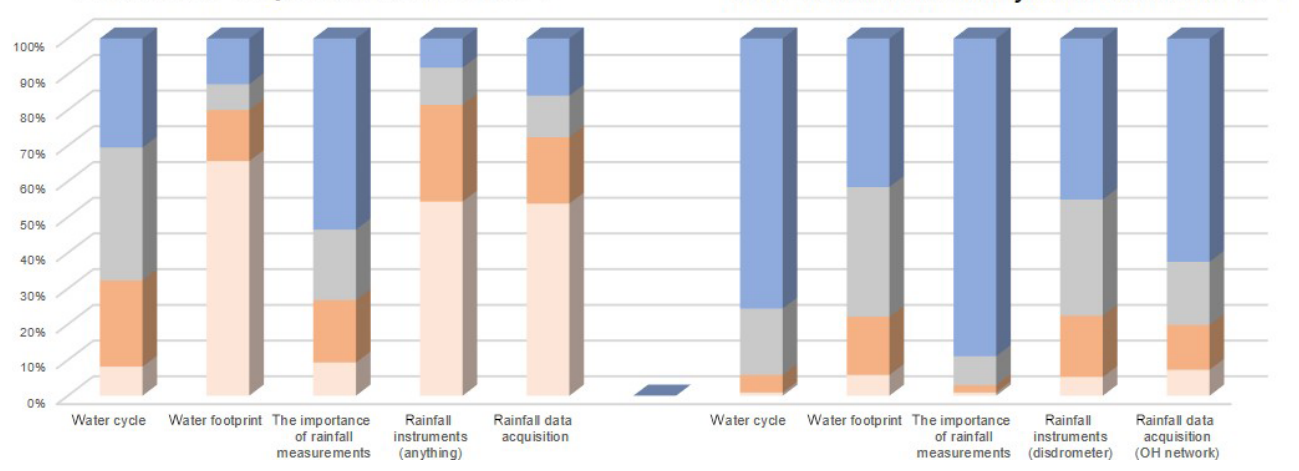

Figure 10. Compilation of answers to questions related to water concepts before (a) and after (b) the workshop.

(a) Diagnostic evaluation

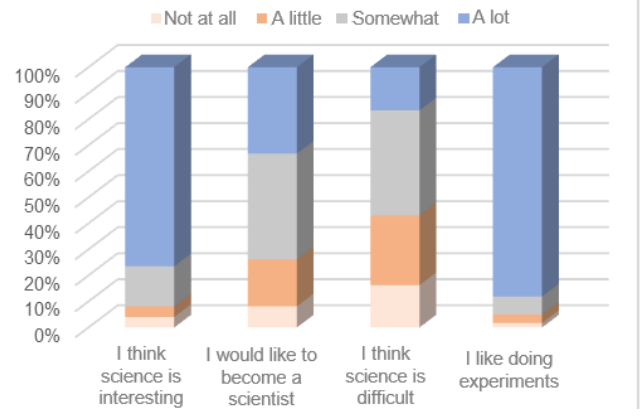

(b) Final evaluation

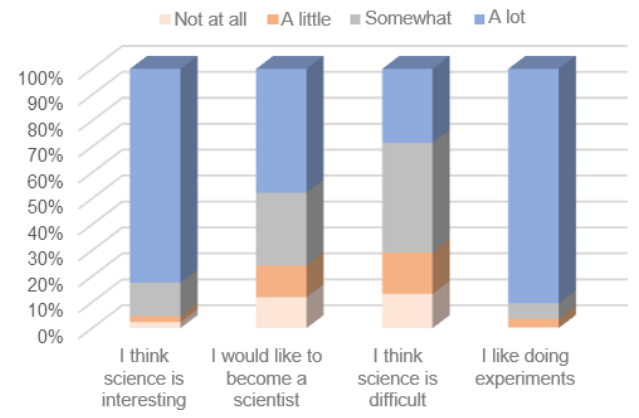

Figure 11. Compilation of answers to questions related to perceptions of science and scientists before (a) and after (b) the workshop.

after the workshop. Indeed, before the workshop, $33.13 \%$ of students answered "a lot" to the question of whether they would like to become a scientist, and the percentage of students giving the same answer to this question after the activities increased to $47.68 \%$.

From the comparative results of each question, along with the perception of the OH-kids team, it is possible to infer that the activities "Urban water physical model" and "Meet and play with a real optical disdrometer" presented a significant contribution to the apparent change in students perceptions of the subjects. As expected, the changes in the answers to questions 1,2 , and 5 may be associated with the efficiency of the short introductory talk, such as the quiz and the remaining ludic activities (bingo, memory, and Hydro-thon), which provided reinforcement of the concepts).

Although changes in percentages before and after the workshop are slight in general, numbers demonstrate that the workshop did in fact have a positive influence on students' ideas and subjects. In general, all students were clearly engaged by the interactive and ludic activities and hands-on experiments, which enhanced their curiosity and sparked their interest in water science and technology.
The confirmation provided by these numbers was further established through personal interviews with educators from all the schools that were visited. In all cases, it was recognized that the workshop was novel at introducing scientific concepts and activities into the classroom. The contextualization of science through the explanation of a real research project with the implementation of different strategies that included hands-on activities and games provided fuel for enthusiasm and energy in most students. In addition, it helped to pass the message to students with different skills and attitudes towards science.

This initiative is observed as a promising first step towards establishing a research-practice partnership between a research institution and different primary schools in the city, which, by the way, have agreed to host an in situ rainfall monitoring station within their facilities. Thus, we were able to cross the boundaries between schools, universities, and researchers, imparting knowledge in a ludic way in order to share information and expertise. Our approach was oriented towards leveraging everyday issues (e.g. lack of water, rainfall measurements) and the skills of a diverse group of students to show them that their innate curiosity is the muchneeded fuel for research. 
It should be noted that it is not the intention of the workshop to replace the classroom instruction, but to provide another learning strategy. In a similar way, games have been reported not to displace classroom instruction, books, and tests (Shapiro et al., 2014). However, our workshop is a viable venue for educators to provide the differentiated learning experiences that students require to find their inner motivation and fulfil their potential. The workshop will be carried out in the following years to continue the engagement of more students in a robust, relevant, and sustainable way that can be upscaled.

\section{Conclusions and final remarks}

Childhood education aiming at incorporating topics related to STEM have gained recognition as key levers in the progress of education for all students. STEM activities are an effective platform for providing rich learning experiences that are accessible to students from all backgrounds.

This study used activities related to a real research project to provide a motivational design for math and science classes. The objective was to enhance the attractiveness and accessibility of STEM topics related to water science in an informal setting, followed by comprehensible teaching and a connection to students' everyday experiences.

This study presented an outreach model entitled $\mathrm{OH}$ Kids, which was designed to empower educators and pupils through the development of high-quality STEM learning experiences. The model presents an opportunity for primary school learners to meet "actual" scientists and, at the same time, receive the take-home message that anyone can get involved in problem-solving activities related to science, regardless of their ability.

The results from the OH-Kids workshop in a sample of 344 students (6-12-year-olds) show that the activities and applied techniques of the workshop provided apparent changes in the initial perceptions of some students about concepts and ideas referring to science and scientists. Furthermore, the results suggest that including different ways of communicating concepts related to STEM disciplines broadens students' interest and motivation.

This was shown by the comparison of answers between the diagnostic and final evaluation questionnaires. It is important to emphasize that one of the limitations of this study is related to the workshop's method of evaluation, because it does not allow changes in the knowledge of the themes covered to be measured.

Our strategy can be considered as an adequate tool for blending communicational boundaries of technical and scientific knowledge between universities and community schools. Often, these boundaries are fixed and do not allow communication between knowledge and application or problems and solutions.
It is acknowledged that even a slight change in the students' perception of STEM disciplines can have very positive implications for their future interest in the subject.

Therefore, it is necessary to extend this type of methodology to take educational research activities - such as our workshop - to a wider audience. For instance, a worthwhile direction for future work would be to explore the implementation of this workshop among marginalized communities.

Data availability. The dataset containing results from this study is now freely available through https://doi.org/10.5281/zenodo. 3556931 (Pedrozo-Acuña et al., 2019).

Author contributions. All authors contributed to the writing of the paper. APA was the lead author and contributed to the development and preparation of activities. RJF Jr. developed the methodology of circuit activity and managed this activity. AAL and RKMK contributed to the development and preparation of the games and introductory talk and were in charge of these activities. JASP, JAMH, and JBF developed the technical part of activities related to the physical model and disdrometer activities, as well as to the presentation of both activities.

Competing interests. The authors declare that they have no conflict of interest.

Acknowledgements. The authors thankfully acknowledge the primary school teachers and principals who allowed the application of this project. Authors are also grateful to Emilio García Díaz from the Mexican Institute of Water Technology for his time invested in the language revision.

Financial support. This research has been supported by Secretaría de Ciencia, Tecnología e Innovación de la Ciudad de México, through project number SECITI/091/2018 and by Dirección General de Asuntos del Personal Académico at UNAM, through research grant PAPIME no. PE101418.

Review statement. This paper was edited by Luis Azevedo Rodrigues and reviewed by two anonymous referees.

\section{References}

Bacon, S. B.: The Evolution of the Outward Bound Process, Colorado Outward Bound Press, Denver, USA, 1987.

Bertram, T. and Pascal, C.: Early childhood policies and systems in eight countries, International Association for the Evaluation of Educational Achievement (IEA), Springer, Cham, 2016.

Bianchi, L. and Chippindall, J.: Learning to teach engineering in the primary and KS3 classroom. A report for the Royal Academy of Engineering, ISBN 978-1-909327-41-2, available at: https: 
//www.raeng.org.uk/tinkering (last access: 19 January 2019), 2018.

Bochennek, K., Wittekindt, B., Zimmermann, S. Y., and Klingebiel, T.: More than mere games: a review of card and board games for medical education, Med. Teach., 29, 941-948, https://doi.org/10.1080/01421590701749813, 2007.

Bodnar, C. A., Anastasio, D., Enszer, J. A., and Buerkey, D. D.: Engineers at play: Games as teaching tools for undergraduate engineering students. The research, Journal for engineering Education, 105, 147-200, https://doi.org/10.1002/jee.20106, 2016.

Brenneman, K., Stevenson-Boyd, J., and Frede, E.: Early mathematics and science: Preschool policy and practice, Preschool Policy Brief, 19, National Institute for Early Education Research, New Brunswick, NJ, 2009.

Brenneman, K., Lange, A., and Nayfeld, I.: Integrating STEM into Preschool Education; Designing a Professional Development Model in Diverse Settings, Early Childhood Educ. J., 47, 15-28, https://doi.org/10.1007/s10643-018-0912-z, 2018.

Butucha, K. G.: Emerging trends in student engagement in the $21 \mathrm{st}$ century contemporary world, Bar. Int. Res. J., 6, 39-43, 2016.

Connolly, T. M., Boyle, E. A., MacArthur, E., Hainey, T., and Boyle, J. M.: A systematic literature review of empirical evidence on computer games and serious games, Comput Educ., 59, 661-86, https://doi.org/10.1016/j.compedu.2012.03.004, 2012.

Croxton, D. and Kortemeyer, G.: Informal physics learning from video games: a case study using gameplay videos, Phys. Edu., 53, 015012, https://doi.org/10.1088/1361-6552/aa8eb0, 2018.

Design-Based Research Collective: Theme issue: The role of design in educational research, Educ. Res., 32, 21-24, 2003.

DeWitt, J. and Archer, L.: Who Aspires to a Science Career? A comparison of survey responses from primary and secondary school students, Int. J. Sci. Educ., 37, 2170-2192, https://doi.org/10.1080/09500693.2015.1071899, 2015.

Drago-Severson, E.: Leading adult learning: Supporting adult development in our schools, Corwin Press, Thousand Oaks, CA, 2009.

Drew, C.: Why science majors change their minds, New York Times, ED16, available at: http: //www.nytimes.com/2011/11/06/education/edlife/

why-science-majors-change-their-mind-its-just-so-darn-hard. html (last access: 14 March 2019), 2011.

Education World: Teaching with games, available at: http:// educationworld.com/a_curr/strategy/strategy065.shtml (last access: 25 February 2019), 2015.

Falk, J. H., Pattison, S., Meier, D., Bibas, D., and Livingston, K.: The contribution of science-rich resources to public science interest, J. Res. Sci. Teach., 55, 422-445, https://doi.org/10.1002/tea.21425, 2017.

Fantuzzo, J. W., Gadsden, V. L., and McDermott, P. A.: An integrated curriculum to improve mathematics, language, and literacy for Head Start children, Am. Educ. Res. J., 48, 763-793, 2011.

Feisel, L. D. and Rosa, A. J.: The role of laboratory un undergraduate engineering education, J. Eng. Educ., 94, 121-130, https://doi.org/10.1002/j.2168-9830.2005.tb00833.x, 2005.

Friedman-Krauss, A. H., Barnett, S. W., Weisenfeld, G. G., Kasmin, R., DiCrecchio, N., and Horowitz, M.: The state of preschool 2017: State preschool yearbook, National Institute for Early Education Research, New Brunswick, 2018.
Garris, R., Ahlers, R., and Driskell, J. E.: Games, Motivation, and Learning: A Research and Practice Model, Simulat. Gaming, 33, 441-467, https://doi.org/10.1177/1046878102238607, 2002.

Gilbert, A. and Byers, C. C.: Wonder as a tool to engage preservice elementary teachers in science learning and teaching, Sci. Educ., 101, 907-928, https://doi.org/10.1002/sce.21300, 2017.

Maltese, A., Melki, C., and Wiebke, H.: The nature of experiences responsible for the generation and maintenance of interest in STEM, Sci. Educ., 98, 937-962, https://doi.org/10.1002/sce.21132, 2014.

Martin, A. J., Durksen, T. L., Williamson, D., Kiss, J., and Ginns, P.: The role of a museum-based science education program in promoting content knowledge and science motivation, J. Res. Sci. Teach., 53, 1364-1384, https://doi.org/10.1002/tea.21332, 2016.

McIntyre, M.: Early childhood and science, National Science Teachers Association, Washington, D.C., 1984.

Millar, R.: Rhetoric and reality: What practical work in science is really for, in: Practical work in school science. Which way now?, edited by: Wellington, J., 16-31, Routledge, London, 1998.

Morgan, P. L., Farkas, G., Hillemeier, M. M., and Maczuga, S.: Science achievement gaps begin very early, persist, and are largely explained by modifiable factors, Educ. Res., 45, 18-35, 2016.

Muller, C. L., Roberts, S., Wilson, R. C., Remedios, J. J., Illingworth, S., Graves, R., Trent, T., Henderson, J., Wilkinson, J., Wilkinson, M., and Desai, A.: The Blue Marble: a model for primary school STEM outreach, Physics Education, 48, 176-183, https://doi.org/10.1088/0031-9120/48/2/176, 2013.

Neame, R. L. and Powis, S. A.: Towards independent learning: curricular design for assisting students to learn how to learn, J. Med. Educ., 56, 886-893, 1981.

OECD: PISA 2015 results (Volume I): excellence and equity in education, OECD Publishing, Paris, https://doi.org/10.1787/9789264266490-en, 2016.

Parson, K. A. and Miles, J. S.: Bio-Pictionary - a scientific party game which helps to develop pictorial communication skills, J. Biol. Educ., 28, 17-18, https://doi.org/10.1080/00219266.1994.9655358, 1994.

Pedrozo-Acuña, A., Magos-Hernández, J. A., Sánchez-Peralta, J. A., Amaro-Loza, A., and Brená-Naranjo, J. A.: Real-time and discrete precipitation monitoring in Mexico City: implementation and application, IAHR, Hydrosenssoft Madrid, Spain, 2017.

Pedrozo-Acuña, A., Favero Jr., R. J., Amaro-Loza, A., MocvaKurek, R. K., Sánchez-Peralta, J. A., Magos-Hernández, J. A., and Blanco-Figueroa, J.: Evaluation data used in "An innovative STEM outreach model (OH-Kids) to foster the next generation of geoscientists, engineers, and technologists", (Version 1), Zenodo, https://doi.org/10.5281/zenodo.3556931, 2019.

Piaget, J.: Science of education and the psychology of the child, Viking Press, New York, 1971.

Poljak, N., Bisilj, A., Brzaj, S., Dragovic, J., Dubcek, T., Erhardt, F., and Jercic, M.: Physionary - a scientific version of Pictionary, Phys. Educ., 53, https://doi.org/10.1088/13616552/aadde4, 2018.

Regan, E. and DeWitt, J.: Attitudes, interest and factors influencing STEM enrolment behaviour: An overview of relevant literature, in: Understanding student participation and choice in science and technology education, edited by: Henriksen, E. K., Dillon, J., and Ryder, J., 63-88, Springer, Dordrecht, https://doi.org/10.1007/978-94-007-7793-4_5, 2015. 
Renninger, K. A. and Su, S.: Interest and its development, in: The Oxford handbook of human motivation, edited by: Ryan, R., 167-187, Oxford University Press, New York, 2012.

Richardson, D. and Birge, B.: Teaching physiology by combined passive (pedagogical) and active (andragogical) methods, Am. J. Physiol., 268, S66-S74, 1995.

Rogers, D. L., Martin, R. E., and Kousaleos, S.: Encouraging science through playful discovery, Day Care and Early Educ. J., 16, 20-23, https://doi.org/10.1007/BF01620353, 1988.

Rozek, C., Hyde, J., Svoboda, R., Hulleman, C., and Harackiewicz, J.: Gender differences in the effects of a utilityvalue intervention to help parents motivate adolescents in mathematics and science, J. Educa. Psychol., 107, 195-206, https://doi.org/10.1037/a0036981, 2015.

Sarama, J., Lange, A. A., Clements, D. H., and Wolfe, C.: The impacts of an early mathematics curriculum on oral language and literacy, Early Child. Res. Q., 27, 489-502, 2012.

Savelsbergh, E. R., Prins, G. T., Rietbergen, C., Fechner, S., Vaessen, B. E., Draijer, J. M., and Bakker, A.: Effects of innovative science and mathematics teaching on student attitudes and achievement: A meta-analytic study, Educ. Res. Rev.-Neth., 19, 158-172, https://doi.org/10.1016/j.edurev.2016.07.003, 2016.

Shapiro, J., Tekinbas, K. S., Schwartz, K., and Darvasi, P.: MindShift Guide to Digital Games and Learning, KQED, available at: https://a.s.kqed.net/pdf/news/ MindShift-GuidetoDigitalGamesandLearning.pdf (last access: 12 April 2019), 2014.

Sheldrake, R.: Students' intentions towards studying science at upper-secondary school: The differential effects of underconfidence and over-confidence, Int. J. Sci. Educ., 38, 12561277, https://doi.org/10.1080/09500693.2016.1186854, 2016.

Sheldrake, R., Mujtaba, T., and Reiss, M. J.: Science teaching and students' attitudes and aspirations: The importance of conveying the applications and relevance of science, Int. J. Educ. Res., 85, 167-183, 2017.
Smith, K. A., Sheppard, S. D., Johnson, D. W., and Johnson, R. T.: Pedagogies of Engagement: Classroom-Based Practices, J. Eng. Educ., 94, 87-101, https://doi.org/10.1002/j.21689830.2005.tb00831.x, 2005.

Souza, P. V. S., Morais, L. P., and Girardi, D.: Spies: An educational game, Phys. Educ., 53, 045012, https://doi.org/10.1088/13616552/aac202, 2018.

Steinberg, S.: The benefits of video games, available at: http://abcnews.go.com/blogs/technology/2011/12/ the-benefits-of-video-games/ (last access: 25 February 2019), 2011.

van Os, A., Soulsby, R., and Kierkegaard, J.: The future role of experimental methods in European. The future role of experimental methods in European hydraulic research: towards a balanced methodology, J. Hydraul. Res., 42, 341-356, https://doi.org/10.1080/00221686.2004.9641203, 2010.

Wilkinson, I. A. G. and Fung, I. Y. Y.: Small-group composition and peer effect, Int. J. Educ. Res., 37, 425-447, 2002.

Windschitl, M., Thompson, J., and Braaten, M.: Ambitious science teaching, Harvard Education Press, Cambridge, MA, 2018.

Zaslow, M., Tout, K., Halle, T., Whittaker, J. E., and Lavelle, B.: Emerging research on early childhood professional development, in: Preparing teachers for the early childhood classroom: Proven models and key principles, edited by: Neuman, S. B. and Kamil, M. L., 19-47, Brookes Publishing, Baltimore, 2010.

Zyda, M.: From visual simulation to virtual reality to games, Computer, IEEE Computer Society, 39, 25-32, https://doi.org/10.1109/MC.2005.297, 2005. 